\title{
Pneumoscrotum as a presentation of necrotising enterocolitis
}

\author{
Suresh Kumar Angurana, ${ }^{1}$ Ravi P Kanojia, ${ }^{2}$ Guruprasad Peruri, ${ }^{1}$ \\ Venkataseshan Sundaram ${ }^{3}$
}

'Department of Pediatrics, Post Graduate Institute of Medical Education and Research, Chandigarh, India ${ }^{2}$ Department of Paediatric Surgery, Post Graduate Institute of Medical Education and Research, Chandigarh, India ${ }^{3}$ Department of Pediatrics, Post Graduate Institute of Medical Education and Research, Chandigarh, India

Correspondence to Suresh Kumar Angurana, sureshangurana@gmail.com

Accepted 29 September 2018

Check for updates

(c) BMJ Publishing Group Limited 2018. No commercial re-use. See rights and permissions. Published by BMJ.

To cite: Angurana SK, Kanojia RP, Peruri G, et al. BMJ Case Rep Published Online First: [please include Day Month Year]. doi:10.1136/bcr-2018227300

\section{DESCRIPTION}

A preterm baby born at 32 weeks of gestation with a birth weight of $1.4 \mathrm{~kg}$ referred to us on day 11 of life with feed intolerance and scrotal swelling. Examination revealed slightly distended abdomen, absent bowel sounds and a huge scrotal swelling which was soft in consistency with shiny skin (figure 1A) and brilliant transillumination (figure 1B). Abdominal radiograph showed air under the right dome of the diaphragm (figure 1C, white arrows) and hugely distended scrotum with gas which was extending up to the inguinal canal (figure 1C, yellow arrows). He was managed as a case of necrotising enterocolitis (NEC) with intravenous antibiotics, nil per oral, gastric aspiration and primary peritoneal drainage (peritoneal drain for 7 days). There was an improvement in abdominal distension, feed intolerance and scrotal swelling (figure 1D); and resolution of air under the diaphragm, and pneumoscrotum (figure 1E). $\mathrm{He}$ was discharged after a hospital stay of 14 days.

Pneumoscrotum is defined as the accumulation of air in the scrotum. It is uncommonly reported in neonates. ${ }^{1-3}$ Air may reach the scrotum by one of the three mechanisms: intraperitoneal air (after gut perforation, referred as scrotal pneumatocele); extraperitoneal air from lungs, mediastinum or retroperitoneum dissecting through fascial planes into the scrotal wall; and local scrotal causes (trauma, gas gangrene). ${ }^{13}$ An inguinal hernia is one of the differentials of brilliant transillumination in the scrotum, but the clinical presentation made us to think of pneumoscrotum. In neonates, pneumoscrotum is commonly due to

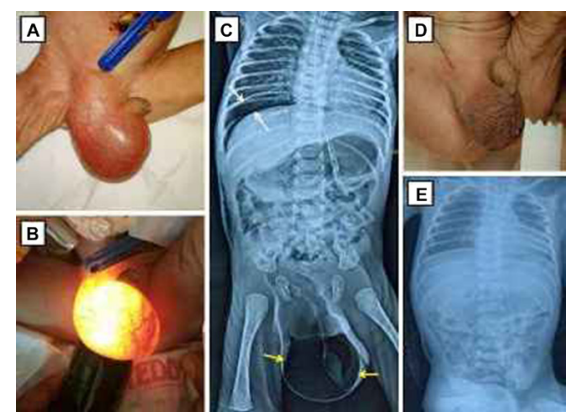

Figure 1 (A) Clinical image showing scrotal swelling with shiny skin. (B) Scrotal swelling showed brilliant transillumination. (C) Abdominal radiograph revealed air under the diaphragm (white arrows) and hugely distended scrotum with gas and gas extending up to the inguinal canal (yellow arrows). (D) Scrotal swelling became passive after 7 days. (E) Abdominal radiograph revealed no air under the diaphragm. bowel perforation, as in index case. ${ }^{1}$ The diagnosis of pneumoscrotum is clinical (inspection and palpation of the scrotum). The radiograph helps in identifying the presence of air in scrotum and determining its origin (peritoneum or thorax). Pneumoscrotum is an important radiographic sign to aid in the diagnosis of bowel perforation especially in neonates and infants. Pneumoscrotum is usually found along with other signs of pneumoperitoneum. Pneumoscrotum per se is a benign medical condition, but the cause of it needs to be identified and treated appropriately based on the primary aetiology and physiological status of the patient. $^{3}$

The index preterm neonate had NEC and intestinal perforation. The reason for pneumoperitoneum is possibly due to the passage of air from peritoneum to scrotum through patent processus vaginalis (which is patent in $80 \%-95 \%$ of newborn males) that caused gaseous distension of scrotum. ${ }^{1}$ Pneumoscrotum was the predominant sign of intestinal perforation in index preterm neonate with NEC which resolved with treatment.

\section{Learning points}

Pneumoscrotum may be the sole obvious manifestation of bowel perforation in preterm neonates and is an important radiographic sign to aid in diagnosis.

- Every effort should be made to find out the site of air leak in a neonate presenting with pneumoscrotum.

Acknowledgements The authors thank Renu Suthar for critically reviewing the case report.

Contributors SKA: supervised patient management and manuscript writing. RPK: surgical management of patient. GP: patient management. VS: supervised patient management.

Funding The authors have not declared a specific grant for this research from any funding agency in the public, commercial or not-for-profit sectors.

Competing interests None declared.

Patient consent Parental/guardian consent obtained.

Provenance and peer review Not commissioned; externally peer reviewed.

\section{REFERENCES}

1 Khan YA, Akhtar J. Pneumoscrotum: a rare presentation of gastric perforation in a neonate. APSP J Case Rep 2010;1:15.

2 Cochetti G, Barillaro F, Cottini E, et al. Pneumoscrotum: report of two different cases and review of the literature. Ther Clin Risk Manag 2015;11:581-7.

3 Millmond SH, Goldman SM. Pneumoscrotum after spontaneous pneumothorax with air leak. J Urol 1991;145:1271-2. 
Copyright 2018 BMJ Publishing Group. All rights reserved. For permission to reuse any of this content visit http://group.bmj.com/group/rights-licensing/permissions.

BMJ Case Report Fellows may re-use this article for personal use and teaching without any further permission.

Become a Fellow of BMJ Case Reports today and you can:

- Submit as many cases as you like

- Enjoy fast sympathetic peer review and rapid publication of accepted articles

Access all the published articles

- Re-use any of the published material for personal use and teaching without further permission

For information on Institutional Fellowships contact consortiasales@bmjgroup.com

Visit casereports.bmj.com for more articles like this and to become a Fellow 